DR. MARÍA PAULINA MONTAÑA (Orcid ID : 0000-0001-7843-9548)

Article type : Research Article

\title{
Oregano essential oil interactions with photogenerated singlet molecular oxygen
}

\author{
Frida C. D. Dimarco Palencia ${ }^{1}$, Vanesa A. Muñoz ${ }^{1}$, Ariana C. Posadaz ${ }^{2}$, Diego A. \\ Cifuente $^{3}$, Sandra Miskoski ${ }^{4}$, Gabriela V. Ferrari ${ }^{1}$, Norman A. García ${ }^{4}$, M. Paulina \\ Montaña ${ }^{1}$
}

${ }^{1}$ Instituto de Química de San Luis INQUISAL (CONICET-UNSL), Área de Química Física, Facultad de Química, Bioquímica y Farmacia, Universidad Nacional de San Luis, D5700HHW San Luis, Argentina.

${ }^{2}$ FTU-UNSL, Área de Formación Básica, Facultad de Turismo y Urbanismo, Universidad Nacional de San Luis, D5881DFN, Merlo, San Luis, Argentina.

${ }^{3}$ Instituto de Tecnología Química INTEQUI (UNSL-CONICET) - Facultad de Química, Bioquímica y Farmacia Área de Química Orgánica, D5700HHW San Luis, Argentina.

${ }^{4}$ Departamento de Química, Facultad de Ciencias Exactas Físico-Químicas y Naturales, Universidad Nacional de Río Cuarto, 5800 Río Cuarto, Argentina.

*Corresponding author’s email: mpaulina.monta.a@gmail.com (M. Paulina Montaña)

This article has been accepted for publication and undergone full peer review but has not been through the copyediting, typesetting, pagination and proofreading process, which may lead to differences between this version and the Version of Record. Please cite this article as doi: 10.1111/PHP.13265

This article is protected by copyright. All rights reserved 


\section{ABSTRACT}

Essential oils are a mixture of volatile compounds, products of the secondary metabolism of plants. Once extracted, they can be deteriorated losing their organoleptic and therapeutic properties due to various environmental factors, being light exposure in aerobic conditions the main cause. In this work the oregano essential oil extraction and characterization from Origanum vulgare plants grown in the experimental field of the FTU-UNSL and its photodegradation in $\mathrm{MeOH}: \mathrm{H}_{2} \mathrm{O}$ 60:40 v/v solvent were studied. Characterization by EIMS and NIST Mass Spectrometry indicates the main compounds of oregano essential oil, quantified in the extracted oil by GC-MS, are carvacrol (7.14\%) and thymol (47.37\%). Degradation of essential oil and its two major components can be caused by reactive oxygen species photogenerated from endogenous sensitizers as riboflavin. Our results suggest degradation occurs involving singlet molecular oxygen. Interaction of carvacrol and thymol with singlet oxygen is mainly a physical process, while essential oil has an important reactive component, which indicates there might be other constituents which could contribute to reactive photoprotection. The effect of simultaneous presence of oregano essential oil and tryptophan aminoacid - used as a photooxidizable model under riboflavin- photosensitizing conditions- was studied in order to evaluate the possible photoprotection exerted by the essential oil.

This article is protected by copyright. All rights reserved 


\section{INTRODUCTION}

Essential oils (EO) are a mixture of aromatic volatile compounds present in specialized cells of certain plants which use them to attract pollinators as well as to protect themselves from predators and pests.(1) Many EO extracted from the Lamiaceae family plants such as lavender(2), lemon balm(3) and oregano(4, 5), among others, have demonstrated antioxidant properties. In particular, antioxidant capacity of oregano essential oil (OEO) has been studied in various extracts obtained from several species of oregano cultivated in a wide variety of locations around the world such as Greece(6), Turkey(7), Colombia(8), China(9), Lithuania(5), Mexico(10), among others.

To understand the antioxidant activity of OEO its chemical composition must be analyzed. Several studies indicate OEO composition includes: p-cymene, terpinenes, flavonoids, among others. However, around $50 \%$ of OEO consists of phenolic compounds, mainly carvacrol (CR) and thymol (TM), two positional isomers of isopropylmethylphenol( $7,9,11,12)$. The structures of both compounds are shown in Figure 1.

Please, insert Figure 1 here

The amount of these major components varies when OEO is extracted from different genera(7), in different seasons or using different cultivation methods(10). It also depends on the age and the development state of the plant(13) and on the part of the plant used(9). Table 1 shows CR and TM composition of OEO extracted from flower and leaf of plants located in different countries.

For instance, OEO from Origanum compactum is a good scavenger of radicals as 2,2-diphenyl-1picrylhydra-zyl (DPPH) and 2,20-azino-bis(3-ethylbenzothiazoline-6-sulphonic acid) (ABTS), property attributed to the presence of CR and TM (14). This activity is similar to the antioxidant activity of Vitamin C (15). Furthermore, authors explain the antioxidant activity considering a possible synergy between the components of OEO (15).

The use of OEO in the pharmaceutical, food and cosmetics industries has gained special interest. The limitation of synthetic food additives in the food industry have fostered their substitution with natural ones $(16,17)$. OEO can be used as a stabilizer of edible oils or of meat products and it even increases the oxidative stability of other products such as fried chips(18). In addition to their 
antioxidant properties, the antimicrobial properties $(7,18)$ of OEO make it a good candidate as a natural preservative $(6,11)$.

Nevertheless, once extracted, OEO can be degraded losing its organoleptic and therapeutic properties due to various environmental factors. Temperature, oxygen availability and light exposure under aerobic conditions are the main causes of this decomposition(19). Degradation of the OEO leads to the generation of allergenic compounds which are responsible for dermatitis, eczemas, among others $(20,21)$. Reactive oxygen species (ROS) photogenerated from endogenous sensitizers can also be the cause of OEO degradation.

In this work, OEO extracted form Origanum vulgare plants in flowering state collected in the experimental field of the FTU-UNSL was characterized and its ROS-mediated degradation was studied. A systematic study of the kinetics and mechanisms involved in the degradation of OEO and its major components TM and CR was performed under visible light irradiation in the presence of vitamin B2. The aim of the study was to establish the contribution of ROS such as singlet molecular oxygen $\left(\mathrm{O}_{2}\left({ }^{1} \Delta_{\mathrm{g}}\right)\right)$ and superoxide radical anion $\left(\mathrm{O}_{2}{ }^{\bullet-}\right)$ in OEO degradation. Considering the possibility of using OEO as a natural preservative, the aminoacid tryptophan (Trp) was used as a typical oxidizable target to evaluate an eventual antioxidant/protective effect of the OEO.

\section{MATERIALS AND METHODS}

Materials. All experiments were made with freshly prepared solutions at room temperature. OEO major components carvacrol (CAS 499-75-2) and thymol (CAS 89-83-8) were provided by Aldrich and Biopack, respectively. Riboflavin (Aldrich, CAS 83-88-5) and Rose Bengal (Anedra, CAS 11121-48-5) were used as sensitizers. Furfuryl alcohol (CAS 98-00-0) and the specific quenchers sodium azide (CAS 26628-22-8), superoxide dismutase (CAS 9054-89-1) and catalase (CAS 9001-05-2) were purchased from Aldrich while L-tryptophan (CAS 73-22-3) was provided by Sigma Chem. All these compounds were used as received.

Acetone (Aldrich, CAS 67-56-1) was used as solvent in the determination of OEO composition while deuterated water $\left(\mathrm{D}_{2} \mathrm{O}\right.$, Aldrich, CAS 7789-20-0) and deuterated methanol (MeOD, Aldrich, CAS 1455-13-06) were employed to enlarge singlet molecular oxygen phosphorescence 
lifetime in TRPD(22). In every other determination methanol HPLC quality (Merck, CAS 67-56-

1) and triply distilled $\mathrm{H}_{2} \mathrm{O}$ were used as solvents in a $\mathrm{MeOH}: \mathrm{H}_{2} \mathrm{O} 60: 40 \mathrm{v} / \mathrm{v}$ ratio.

OEO extraction. OEO was extracted by hydrodistillation with Clevenger trap from Origanum vulgare plants in flowering state collected in the experimental field of the FTU-UNSL. This technique extracts OEO placing a mixture of the vegetable material (leaf and flower milled and dried) and water in a hydrodistillator. The heating releases the OEO, which evaporates due to its high volatility and the mixture of steam and essential oil flows to a condenser. The essential oil can be separated from the condensed liquid by its very low miscibility in water. Further details of this technique can be found in the literature(23).

Photolysis. Stationary aerobic photolysis of solutions containing CR, TM or OEO

$(0.2 \mathrm{mM})$ and $\mathrm{Rf}$ or RB were carried out in a home-made photolyzer for nonmonochromatic irradiation (150 W quartz-halogen lamp) with a $400 \mathrm{~nm}$ cutoff filter, ensured that the light was only absorbed by the sensitizer. The Scheme 1 depicts the irradiation experiment.

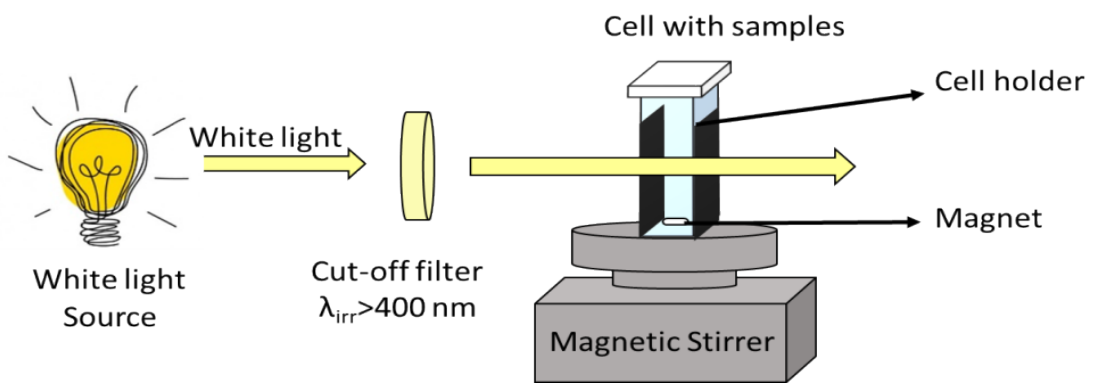

Scheme 1. Diagram of

irradiation experiment.

Sample preparation. Individual stock solutions of every substrate (TM, CR and OEO) of known concentration were prepared using $\mathrm{MeOH}$ as solvent. The sensitizer solution ( $\mathrm{Rf}$ or $\mathrm{RB}$ ) was prepared in a mixture of 60:40 MeOH:H2O and $2.5 \mathrm{~mL}$ of this solution was placed in a quartz cell. An appropriate volume of stock solution was added such that the concentration of the substrate in the cell is $0.2 \mathrm{mM}$. The cell was irradiated and the photolysis was followed by UV-Vis spectrometry.

Determination of OEO composition. The main components of OEO were characterized by EIMS and NIST Mass Spectrometry Data Center, using a Varian Saturn 2000 equipment and employing 
a capillary column Varian C.S. The qualitative analysis using Gas Chromatography-Mass Spectrometry was performed with a Finnigan-Mat-GCQ-plus Gas Chromatography equipment with a Mass Spectrometer (ion trap) detector, equipped with a Testek 5MS capillary column of 30 $\mathrm{m}$ length, $0.25 \mathrm{~mm}$ internal diameter and $0.25 \mu \mathrm{m}$ film thickness. The injection mode used was in Split with a ratio of $1: 25$. The mass spectra were obtained with in a mass range $(\mathrm{m} / \mathrm{z})$ of $28-400 \mathrm{u}$, with an ionization voltage of $70 \mathrm{eV}$.

In addition, CR and TM were quantified in the extracted oil by gas chromatography using a Clarus 500 Perkin-Elmer chromatograph, equipped with a flame ionization detector (FID) using a Quadrex capillary column, 007 methyl 5\% phenyl silicone $30 \mathrm{~m}$ long, $0.25 \mathrm{~mm}$ internal diameter and $0.25 \mu \mathrm{m}$ film thickness. The temperature program of the column employed was: initial temperature $60{ }^{\circ} \mathrm{C}$ maintained five minutes, followed by an increase to $180{ }^{\circ} \mathrm{C}$ at a rate of 3 ${ }^{\circ} \mathrm{C} /$ min gradient and then, a gradient of $20{ }^{\circ} \mathrm{C} /$ min was used until reaching $280{ }^{\circ} \mathrm{C}$, maintaining this temperature for $10 \mathrm{~min}$. The carrier gas was nitrogen at a flow of $1 \mathrm{~mL} / \mathrm{min}$. The FID was maintained at a temperature of $250{ }^{\circ} \mathrm{C}$ and the injector at $220{ }^{\circ} \mathrm{C}$.

Spectrophotometric techniques. An Agilent 8453 diode array spectrophotometer provided with an Agilent 89090A temperature controller was used to record UV-Vis spectra. A $1 \mathrm{~cm}$ pathlength quartz cell with hermetical Teflon cover was used.

ROS deactivation. The possible photogeneration of ROS in solutions containing riboflavin (Rf), and/or their possible deactivation caused by OEO, CR or TM can be qualitatively evaluated through oxygen consumption in the presence of specific quenchers of ROS. Three specific quenchers were used in this work: sodium azide $\left(\mathrm{NaN}_{3}\right)$ which physically deactivates $\mathrm{O}_{2}\left({ }^{1} \Delta_{\mathrm{g}}\right)$, and the enzymes superoxide dismutase (SOD) and catalase (CAT), which are capable of dismutate $\mathrm{O}_{2}^{\bullet}$-and decompose $\mathrm{H}_{2} \mathrm{O}_{2}$ respectively. (24),(25),(26)

To determinate the rates of oxygen uptake (ROU), the sample solution was poured into a $50 \mathrm{~mL}$ pyrex tube and the specific oxygen electrode Orion $810 \mathrm{~A}+$ is submerged in it. The tube was hermetically sealed and the system was irradiated under magnetic stirring. The sample was irradiated employing a $150 \mathrm{~W}$ quartz-halogen lamp and a $400 \mathrm{~nm}$ cut-off filter was used in order to assure neither OEO nor its major components absorb any incident light. 
Quenching of Rf electronically excited states. OEO or its major components could be able to quench ${ }^{1} \mathrm{Rf}^{*}$, first electronically excited singlet state of $\mathrm{Rf}$ (process (4), Scheme 2). In order to evaluate this deactivation, the rate constant, ${ }^{1} k_{\mathrm{q}}$, was determined. A classical Stern-Volmer treatment was employed according to the expression $I_{0} / I=1+K \operatorname{sv}[Q]$, where $I_{0}$ and $I$ are the respective stationary fluorescence intensities in the absence and in the presence of different concentrations of quenchers: OEO or CR or TM, represented by [Q]. Ksv is the Stern-Volmer constant: $\mathrm{Ksv}={ }^{1} k_{\mathrm{q}}{ }^{1} \tau_{0}$, where ${ }^{1} \tau_{0}=5 \mathrm{~ns}$, the Rf fluorescence lifetime(27). Stationary Rf fluorescence experiments were carried out in a Fluoromax-4 Horiba Jobin Yvon spectrofluorometer at $25 \pm 1{ }^{\circ} \mathrm{C}$. The excitation wavelength was $445 \mathrm{~nm}$ while emission wavelength was measured at $515 \mathrm{~nm}$.

OEO or its major components could also deactivate ${ }^{3} \mathrm{Rf}^{*}$, triplet electronically excited of $\mathrm{Rf}$ (process (5) Scheme 2). The rate constants, ${ }^{3} k_{\mathrm{q}}$, for this quenching were determined using Laser Flash Photolysis (LFP) method. In this method Ar-saturated aqueous solutions of Rf were photolyzed using a Nd:YAG laser system (Spectron) and an excitation source at $355 \mathrm{~nm}$, with a $150 \mathrm{~W}$ Xenon lamp as the analyzing light. A PTI monochromator and a red-extended photomultiplier (Hamamatsu R666) were used as detection system. The signal, acquired and averaged by a digital oscilloscope (Hewlett-Packard 54504A), was transmitted to a PC via a HPIB parallel interface where it was analyzed and stored. ${ }^{3} \mathrm{Rf}^{*}$ was generated by a $355 \mathrm{~nm}$ laser pulse and its disappearance was monitored from the first-order decay of the absorbance at $670 \mathrm{~nm}$, a wavelength where other possible species do not interfere. Self-quenching and triplet-triplet annihilation were avoided measuring the triplet decay at low concentration of $\mathrm{Rf}(0.05 \mathrm{mM})$ and at low laser energy. The rate constants were determined employing a Stern-Volmer treatment according to the expression ${ }^{3} \tau_{0} /{ }^{3} \tau=1+{ }^{3} \mathrm{k}_{q}[\mathrm{Q}]$, where ${ }^{3} \tau_{0}$ and ${ }^{3} \tau$ are the respective lifetimes in the absence and in the presence of different concentrations of quencher: OEO or CR or TM, represented by $[\mathrm{Q}]$ in the equation above.

$\mathrm{O}_{2}\left({ }^{1} \Delta_{\mathrm{g}}\right)$ interaction. The rate constants for overall quenching of $\mathrm{O}_{2}\left({ }^{1} \Delta_{\mathrm{g}}\right), k_{\mathrm{t}}$, by the OEO and its major components $\mathrm{CR}$ and TM were determined by means of time resolved phosphorescence detection (TRPD)(28). In this method, $\mathrm{O}_{2}\left({ }^{1} \Delta_{\mathrm{g}}\right)$ was generated using Rose Bengal (RB) as sensitizer, which was excited by irradiating the aerated solutions with $532 \mathrm{~nm}$ light from a Nd:YAG laser (Spectron), after filtering it with appropriate filters. The phosphorescence signal at $1270 \mathrm{~nm}$ of $\mathrm{O}_{2}\left({ }^{1} \Delta_{\mathrm{g}}\right)$ emission was detected at right angle using an amplified Judson J16/8 Germanium detector. $\mathrm{O}_{2}\left({ }^{1} \Delta_{\mathrm{g}}\right)$ lifetimes were evaluated in the absence, $\tau_{0}$, and in the presence, $\tau$, of 
the quencher: $\mathrm{OEO}$ or CR or TM. The data were plotted according to a simple Stern-Volmer treatment: $\tau_{0} / \tau=1+k_{\mathrm{t}} \tau_{0}[\mathrm{Q}]$, being $[\mathrm{Q}]=[\mathrm{OEO}]$ or $[\mathrm{CR}]$ or $[\mathrm{TM}]$, alternatively.

The rate constant for the reaction OEO, CR or TM and $\mathrm{O}_{2}\left({ }^{1} \Delta_{\mathrm{g}}\right), k_{\mathrm{r}}$, (process (15), Scheme 2) was evaluated employing an actinometrical method.(29) According to this method, $k_{\mathrm{r}}$ of a sample is determined from slopes of the first-order plots of oxygen uptake in the presence of a sample (OEO or its major components) and a reference (R) upon photosensitized irradiation using the following expression: slope/slope $\mathrm{R}_{\mathrm{R}}=k_{\mathrm{r}} / k_{\mathrm{rR}}$. The reference used was furfuryl alcohol (FFA), with a reported $k_{\mathrm{rR}}$ value of $3 \times 10^{7} \mathrm{~L} \mathrm{~mol}^{-1} \mathrm{~s}^{-1}$ in methanolic media.(30) The ROU were determined as described in section 2.3 .3

OEO and its major components as photo-protectors of Tryptophan. Relative rates for Rf sensitized photooxidation of the systems, Trp, OEO and their mixtures were evaluated through the initial slope of oxygen consumption as a function of photoirradiation time, employing the specific oxygen electrode already described. Normalized rates were obtained as the quotient between the respective ROUs for a given sample and for the faster oxygen-consumer sample. The experiments were carried out until $10-15 \%$ of oxygen consumption as a measure of the photooxidability of each studied system.

\section{RESULTS AND DISCUSSION}

\section{OEO composition}

The main components of OEO were characterized by employing EIMS and NIST Mass Spectrometry Data Center techniques. Figure 2 shows the obtained chromatogram which allowed the determination of several compounds in the OEO extracted. They are listed in Table 2 including their retention times (RT).

Please, insert Figure 2 here

Considering the peak areas, the first major component in the OEO is TM while CR is the second major component. In order to quantify TM present in the OEO by means of gas chromatography it 
was necessary to plot a calibration curve by an external standard quantification method, injecting solutions of 20,60 and $80 \mathrm{mg} / \mathrm{mL}$ of TM using acetone as solvent. As CR and TM have a similar chemical structure, the same calibration curve was used to calculate CR concentration.

Final results of TM and CR quantification showed OEO was $47.37 \% \mathrm{w} / \mathrm{v}$ TM and $7.14 \% \mathrm{w} / \mathrm{v}$ CR. This is consistent with the previously reported analysis which indicated around $50 \%$ of OEO consists of phenolic compounds, mainly CR and TM.(7, 9, 11, 12)

Since OEO is a complex mixture, the concentration of the major component (TM) was used as a way to express OEO concentration. This will be henceforth indicated as $\mathrm{TM}_{\mathrm{OEO}}$, and it means TM concentration in OEO.

\section{Photolysis of OEO in the presence of sensitizers}

Before performing any stationary photolysis experiment, associations between sensitizers, Rf and $\mathrm{RB}$, and $\mathrm{OEO}, \mathrm{CR}$ or TM were evaluated. These evaluations were performed by recording the spectra of a solution of Rf and the same solutions with different concentrations of OEO, CR or TM. No associations were observed between these compounds and no spectral changes were observed in absence of light (data not shown), hence photolysis experiments were carried out.

In order to perform photolysis experiments, it was necessary to select a wavelength where only the sensitizer, Rf, absorbs. Figure 3 shows absorption spectra of the individual solutions of the three studied compounds and absorption spectrum of riboflavin. Considering these figure a $400 \mathrm{~nm}$ cut off filter proved to be useful to prevent absorption of any compound except Rf. In consequence this filter was selected to perform photolysis experiments. The molar absorption coefficients of TM and CR were also evaluated at $274 \mathrm{~nm}$, and results obtained are shown in Table 3.

Please, insert Figure 3 here

Sensitized photoirradiation of aerated solutions of OEO in the presence of $\mathrm{Rf} v \mathrm{vf}$ is shown in Figure 4. Spectral evolution of $\mathrm{Rf}$ is also included (inset). Both systems experimented modifications in their respective absorption spectra which can be attributed to chemical changes involving the substrate, OEO, or the mixture substrate+Rf. The slight negative absorbance observed in the 450-500 $\mathrm{nm}$ wavelength regions corresponds to Rf degradation. Similar qualitative results were obtained for $\mathrm{CR}$ and $\mathrm{TM}$ (data not shown). This result means Rf 
electronically excited states and/or ROS generated from them may be responsible for the photoreactions.

Please, insert Figure 4 here

In order to understand the mechanism of interaction of OEO, CR and TM with photoexcited Rf, Scheme 2 was employed. This scheme has been used in previous investigations carried out by our research group(31-35).

$$
\begin{aligned}
& \mathrm{Rf}+\mathrm{h} v \rightarrow{ }^{1} \mathrm{Rf}^{*} \rightarrow{ }^{3} \mathrm{Rf}^{*} \\
& { }^{1} \mathrm{Rf}^{*}+\mathrm{Q} \rightarrow \stackrel{k_{\mathrm{q}(1)}}{\rightarrow \mathrm{Rf}}+\mathrm{Q} \text { o } \mathrm{P}(2) \\
& { }^{3} \mathrm{Rf}^{*}+\mathrm{O}_{2}\left({ }^{3} \Sigma_{\mathrm{g}}^{-}\right) \rightarrow \mathrm{Rf}^{++}+\mathrm{O}_{2}^{\cdot-} \\
& { }^{3} \mathrm{Rf}^{*}+\mathrm{Q} \stackrel{k_{\mathrm{q}(3)}}{\rightarrow} \mathrm{Rf}^{-}+\mathrm{Q}^{\cdot+} \\
& \mathrm{Rf}^{-}+\mathrm{H}^{+} \rightarrow \mathrm{RfH}^{\bullet} \\
& 2 \mathrm{RfH}^{\bullet} \rightarrow \mathrm{Rf}+\mathrm{RfH}_{2} \\
& \mathrm{RfH}_{2}+\mathrm{O}_{2}\left({ }^{3} \Sigma_{\mathrm{g}}{ }^{-}\right) \rightarrow \mathrm{RfH}_{2}{ }^{\cdot+}+\mathrm{O}_{2}{ }^{\cdot-} \\
& \mathrm{RfH}_{2}{ }^{\cdot+}+\mathrm{O}_{2}{ }^{--}-\longrightarrow \mathrm{Rf}+\mathrm{H}_{2} \mathrm{O}_{2} \\
& \mathrm{O}^{2 \bullet-}+\mathrm{Q} \rightarrow \mathrm{P}(9) \\
& { }^{3} \mathrm{Rf}^{*}+\mathrm{O}_{2}\left({ }^{3} \Sigma_{\mathrm{g}}{ }^{-}\right) \stackrel{k_{\mathrm{ET}}}{\rightarrow} \mathrm{Rf}+\mathrm{O}_{2}\left({ }^{1} \Delta_{\mathrm{g}}\right) \\
& \mathrm{O}_{2}\left({ }^{1} \Delta_{\mathrm{g}}\right) \stackrel{k_{\mathrm{d}}}{\rightarrow} \mathrm{O}_{2}\left({ }^{3} \Sigma_{\mathrm{g}}\right) \\
& \mathrm{O}_{2}\left({ }^{1} \Delta_{\mathrm{g}}\right)+\mathrm{Q} \stackrel{k_{\mathrm{q}}}{\rightarrow} \mathrm{O}_{2}\left({ }^{3} \Sigma_{\mathrm{g}}{ }^{-}\right)+\mathrm{Q} \\
& \mathrm{O}_{2}\left({ }^{1} \Delta_{\mathrm{g}}\right)+\mathrm{Q} \stackrel{k_{\mathrm{r}}}{\rightarrow} \mathrm{P}(13)
\end{aligned}
$$

$$
\text { Being: } k_{\mathrm{t}}=k_{\mathrm{r}}+k_{\mathrm{q}}
$$


Scheme 2. Kinetic mechanism of Rf as a sensitizer in the presence of an electron donor (Q) and oxygen donor $\left(\mathrm{O}_{2}\right)$.

According to this scheme the absorption of incident light by the sensitizer Rf, leads it to electronically excited singlet and triplet states according to process (1). Both electronically excited states of $\mathrm{Rf}$ can be deactivated in presence of a quencher (Q), an electron donor wich des not absorb in the wavelength range used. through processes (2) and (4). ${ }^{3} \mathrm{Rf}^{*}$ can also interact with the ground state triplet molecular oxygen $\left(\mathrm{O}_{2}\left({ }^{3} \Sigma_{\mathrm{g}}\right)\right)$ through process (3) . By means of an electron transfer reaction, process (4), the semireduced $\mathrm{Rf}$ and semioxidized Q forms are produced. Process (7) generates the reactive species $\mathrm{O}_{2}{ }^{\bullet-}$ which can react with $\mathrm{Q}$, process (9). $\mathrm{P}(2)-\mathrm{P}(9)$ represent eventual photoproducts. An energy transfer reaction from the triplet state of $\mathrm{Rf}$ to $\mathrm{O}_{2}\left({ }^{3} \Sigma_{\mathrm{g}}{ }^{-}\right)$, which is dissolved in the medium, can take place yielding $\mathrm{O}_{2}\left({ }^{1} \Delta_{\mathrm{g}}\right)$, process $(10) . \mathrm{O}_{2}\left({ }^{1} \Delta_{\mathrm{g}}\right)$ can decay by collision with surrounding solvent molecules, process (11), or by interaction with Q and/or Rf through an exclusive physical, process (12), or chemical way, process (13). An overall rate constant for $\mathrm{O}_{2}\left({ }^{1} \Delta_{\mathrm{g}}\right)$ quenching $\left(\mathrm{k}_{\mathrm{t}}\right)$ is defined as the sum of the rate constants for processes (12) and (13).

\section{Interaction with photogenerated ROS}

The participation of ROS was evaluated, as described previously through oxygen consumption experiments in the presence of specific quenchers. The quenchers used were: sodium azide, a physical quencher of $\mathrm{O}_{2}\left({ }^{1} \Delta_{\mathrm{g}}\right)$, SOD, which dismutates $\mathrm{O}_{2}{ }^{--}$, and CAT, an enzyme responsible for the decomposition of $\mathrm{H}_{2} \mathrm{O}_{2}$. These selective quenchers in concentrations similar to those employed in this work have been used to confirm or discard the participation of any of those species in a given reaction mechanism $(36,37)$.

The study was first performed using the isomers CR and TM as substrates. Figure 5 shows the oxygen uptake results obtained upon photoirradiation of $\mathrm{Rf}(0.04 \mathrm{mM})$, the mixture $\mathrm{Rf}(0.04 \mathrm{mM})$ $+\mathrm{CR}$ or TM $(0.2 \mathrm{mM})$ and the mixtures $\mathrm{Rf}(0.04 \mathrm{mM})+\mathrm{CR}$ or TM $(0.2 \mathrm{mM})+$ every individual quencher.

Please, insert Figure 5 here

This article is protected by copyright. All rights reserved 
The use of specific ROS scavengers indicates that the photodegradation of both isomers is mainly caused by the presence of $\mathrm{O}_{2}\left({ }^{1} \Delta_{\mathrm{g}}\right)$ since a decrease in the ROU of the mixtures is produced in the presence of $5 \mathrm{mM} \mathrm{NaN}_{3}$. Participation of the species $\mathrm{H}_{2} \mathrm{O}_{2}$ is suggested in the reaction mechanism of TM since a decrease in the ROU of the mixture is produced in the presence of $1 \mu \mathrm{g} / \mathrm{mL}$ CAT. This quencher is capable of decomposing $\mathrm{H}_{2} \mathrm{O}_{2}$ according to the following reaction:

$$
2 \mathrm{H}_{2} \mathrm{O}_{2} \stackrel{C A T}{\longrightarrow} 2 \mathrm{H}_{2} \mathrm{O}+\mathrm{O}_{2}\left({ }^{3} \Sigma_{\mathrm{g}}{ }^{-}\right)
$$

An increase of the ROU of the mixture is produced in the presence of $1 \mu \mathrm{g} / \mathrm{mL}$ SOD. SOD is a specific quencher responsible for the dismutation of $\mathrm{O}_{2}{ }^{--}$according to the following reaction:

$2 \mathrm{O}_{2}^{\bullet-}+2 \mathrm{H}^{+} \stackrel{S O D}{\longrightarrow} \mathrm{O}_{2}\left({ }^{3} \Sigma_{\mathrm{g}}^{-}\right)+\mathrm{H}_{2} \mathrm{O}_{2}$

It has been reported that SOD can favor or inhibit the rate of an oxidative process mediated by $\mathrm{O}_{2}{ }^{--}$on different substrates in which $\mathrm{H}_{2} \mathrm{O}_{2}$ participates as an oxidative species.(38) The peroxide, product of dismutation of $\mathrm{O}_{2}{ }^{--}$by SOD, oxidizes the substrate and contributes to the global consumption of oxygen.

$\mathrm{CR}$ reaction mechanism seems to be different since no effect is observed in the presence of 1 $\mu \mathrm{g} / \mathrm{mL}$ SOD, suggesting that the species $\mathrm{O}_{2}{ }^{-}$is not involved, while the presence of $1 \mu \mathrm{g} / \mathrm{mL}$ CAT increases the rate of oxygen uptake. There is no conclusive explanation to justify the increase in oxygen consumption due to the presence of CAT, which eliminates $\mathrm{H}_{2} \mathrm{O}_{2}$ and generates molecular oxygen (reaction (15)). One possible explanation is that the latter is incorporated into the $\mathrm{O}_{2}\left({ }^{1} \Delta_{\mathrm{g}}\right)$ generation cycle (step (11) Scheme 2) and this species oxidizes CR in a more efficient reaction than the reaction against $\mathrm{H}_{2} \mathrm{O}_{2}$.

To increase the knowledge about the reaction mechanism involved in the interaction of OEO and ROS photogenerated from Rf, a similar experiment was carried out replacing the isomers by OEO.

Figure 6, Left shows that $\mathrm{O}_{2}\left({ }^{1} \Delta_{\mathrm{g}}\right)$ is the only ROS involved in the oxidation mechanism of the OEO. This can be inferred from the decrease in the ROU of the mixtures in the presence of $5 \mathrm{mM}$ $\mathrm{NaN}_{3}$. Participation of the species $\mathrm{O}_{2}{ }^{--}$and $\mathrm{H}_{2} \mathrm{O}_{2}$ can be discarded since no change was observed in the oxygen uptake profiles in the presence of their respective quenchers. The absence of changes in the ROU in the presence of CAT could be explained considering the opposite effect of CR and TM individually. In order to prove this hypothesis, the same experiment was repeated 
replacing OEO with a mixture of CR and TM in the same proportions found in the OEO (Figure 6, Right). Results show no changes in the ROU of the mixture in presence of CAT, evidencing that the effect of this inhibitor is compensated by the combined actions of CR and TM individually. The presence of SOD produces an increase of the ROU of the mixture, the same effect observed for TM (Figure 5, Left), suggesting other components might be interacting to eliminate this effect in the OEO.

\section{Please, insert Figure 6 here}

To gain insight in the reaction mechanisms of OEO, CR and TM interaction with Rf photogenerated ROS, kinetic constants of quenching of ${ }^{1} \mathrm{Rf}^{*},{ }^{3} \mathrm{Rf}^{*}$ and total and reactive quenching of $\mathrm{O}_{2}\left({ }^{1} \Delta_{\mathrm{g}}\right)$ were investigated.

\section{Quenching of Rf electronically excited states}

OEO quench the first excited state of $\mathrm{Rf},{ }^{1} \mathrm{Rf}^{*}$, as Figure 7, stationary fluorescence measurements indicates. The same behavior was observed for its major components TM and CR (Figures S1 and $\mathrm{S} 2$ of Supporting Information). The ${ }^{1} k_{\mathrm{q}}$ values were obtained by a Stern Volmer treatment (Figure 7, Inset) and are close to the diffusion limit and the three of them are listed in Table 3. These values are high enough to state that the use of quencher concentration $\sim 10^{-4} \mathrm{M}$, concentrations employed in this work, does not appreciably deactivate the first excited state of $\mathrm{Rf}$ (process (2) Scheme 2).

Please, insert Figure 7 here

Quenching of triplet excited state of Rf, ${ }^{3} \mathrm{Rf}^{*}$, by OEO and its major components TM and CR was studied by LFP. Figure 7 shows the Stern-Volmer plots for every studied system while ${ }^{3} k_{\mathrm{q}}$ values are listed in Table 3.

Cardoso et al. evaluated ${ }^{1} k_{\mathrm{q}}$ for CR and TM in methanol and ${ }^{3} k_{\mathrm{q}}$ in 1:1 acetonitrile:citrate buffer (pH 4.6, $10 \mathrm{mM})$ at 298 K.(39) The authors informed rate constant values of the same order than the values determined in the present work, despite the fact that the reaction media is different in both cases. 
The rate constant for the quenching of ${ }^{1} \mathrm{Rf}^{*}$ by $\mathrm{OEO}$ exceeds three times the value obtained for $\mathrm{CR}$ and TM individually, indicating other components must be responsible for this deactivation in the OEO.

\section{Interaction with $\mathrm{O}_{2}\left({ }^{1} \Delta_{\mathrm{g}}\right)$}

The rate constant of total singlet molecular oxygen deactivation, $k_{\mathrm{t}}$, by OEO, TM and CR were determined by means of TRPD. Results are shown in Figure 8 and $k_{\mathrm{t}}$ values are informed in Table 3. The rate constants of reactive singlet molecular oxygen deactivation, $k_{\mathrm{r}}$, by OEO, TM and CR were evaluated employing the actinometrical method previously described. Results are shown in Figure 8, Inset while Table 3 lists the obtained $k_{\mathrm{r}}$ values.

The values of $\mathrm{k}_{r}$ and $\mathrm{k}_{t}$ are similar for both isomers and they are of the same order that OEO $\mathrm{k}_{r}$ value. The $\mathrm{k}_{r} / \mathrm{k}_{t}$ ratio was also evaluated and informed in Table 3. This ratio indicates the fraction of overall quenching of $\mathrm{O}_{2}\left({ }^{1} \Delta_{\mathrm{g}}\right)$ by every substrate that effectively leads to a chemical transformation. Results suggest that TM and CR are responsible for the deactivation of this oxidative species predominantly via a physical mechanism, a characteristic of interest for a protector against this oxidative species. The individual inhibitory capacity of both major components of OEO is not reflected in the same magnitude in the OEO $\mathrm{k}_{r} / \mathrm{k}_{t}$ ratio, since half of the interactions between it and $\mathrm{O}_{2}\left({ }^{1} \Delta_{\mathrm{g}}\right)$ lead to a chemical transformation. The probable reason of this behaviour is the occurrence of other reactive routes.

\section{Please, insert Figure 8 here}

\section{Photooxidation of tryptophan in the presence of OEO}

The rate of oxygen consumption in systems where OEO and a model amino acid are present provides information to understand if any photoprotection of the protein residues is exerted by OEO. Trp interacts with $\mathrm{O}_{2}\left({ }^{1} \Delta_{\mathrm{g}}\right)$ and the $\mathrm{k}_{t}$ and $\mathrm{k}_{r}$ values are known: $7.2 \times 10^{7} \mathrm{M}^{-1} \mathrm{~s}^{-1}$ and $4.7 \times 10^{7}$ $\mathrm{M}^{-1} \mathrm{~S}^{-1}$ respectively.(40)

To evaluate the photoprotection effect, the ROUs of mixtures of $\mathrm{Rf}+\operatorname{Trp}, \mathrm{Rf}+\mathrm{OEO}$ and $\mathrm{Rf}+\operatorname{Trp}$ + OEO were performed (Figure 9). The ROU of Trp in the presence of the OEO is lower than the rate of both individual substrates, which would indicate that the OEO protects the amino acid in 
the tested conditions. OEO could be considered a sacrificial scavenger due to the high reactive component of its deactivation process.

Please, insert Figure 9 here

\section{CONCLUSION}

The ROS photogenerated by sensitization react with the OEO and its major components. OEO degradation proceed involving mainly $\mathrm{O}_{2}\left({ }^{1} \Delta_{\mathrm{g}}\right)$ and, according to the $\mathrm{k}_{r} / \mathrm{k}_{t}$ ratio value the process of deactivation of this species occurs simultaneously through a chemical and a physical pathway resulting in a not negligible degradation of the OEO. CR and TM deactivate $\mathrm{O}_{2}\left({ }^{1} \Delta_{\mathrm{g}}\right)$ mainly in a physical fashion. The mechanism of the sensitized degradation of TM involves $\mathrm{H}_{2} \mathrm{O}_{2}$, ROS generated as a process intermediary. CR showed a more complex interaction with $\mathrm{H}_{2} \mathrm{O}_{2}$. This interaction regenerates molecular oxygen which may be incorporated in the $\mathrm{O}_{2}\left({ }^{1} \Delta_{\mathrm{g}}\right)$ generation cycle, leading to a more efficient oxidation of the substrate. Finally, it is also possible to infer that the OEO might act as a sacrificial scavenger and exert a protective effect of the amino acid model used in the present study.

\section{SUPPORTING INFORMATION}

Additional supporting information may be found online in the Supporting Information section at the end of the article:

Figure S1. Fluorescence emission spectra of Rf in the presence of increasing concentration of TM. Solvent: $\mathrm{MeOH}: \mathrm{H}_{2} \mathrm{O} 60: 40 \mathrm{v} / \mathrm{v} ; \lambda_{\text {excitation }}=445 \mathrm{~nm}$.

Figure S2. Fluorescence emission spectra of $\mathrm{Rf}$ in the presence of increasing concentration of CR. Solvent: $\mathrm{MeOH}: \mathrm{H}_{2} \mathrm{O} 60: 40 \mathrm{v} / \mathrm{v} ; \lambda_{\text {excitation }}=445 \mathrm{~nm}$.

\section{ACKNOWLEDGEMENTS}


Financial support from CONICET (PIP 11220170100208CO) and SCyT of the Universidad Nacional de San Luis (PROICO 2-3218-22Q/809) and Universidad Nacional de Río Cuarto, all from Argentine, are grateful acknowledged.

We appreciate language revision by staff from Instituto de Lenguas, UNSL.

\section{REFERENCES}

1. Butnario, M. and Sarac, I. (2018) Essential Oils from Plants. J. Biotechnol. Biomed. Sci. 1, 3543. https://doi.org/10.14302/issn.2576.

2. Nurzyńska-Wierdak, R. and Zawiślak, G. (2016) Chemical composition and antioxidant activity of lavender (Lavandula angustifolia Mill .) aboveground parts. Acta Sci. Pol. Hortorum Cultus 15, $225-241$.

3. Gayoso, L., Roxo, M., Cavero, R. Y., Calvo, M. I., Ansorena, D., Astiasarán, I. and Wink, M. (2018) Bioaccessibility and biological activity of Melissa officinalis, Lavandula latifolia and Origanum vulgare extracts: Influence of an in vitro gastrointestinal digestion. J. Funct. Foods 44, 146-154. https://doi.org/10.1016/j.jff.2018.03.003.

4. Schwarz, M., Zeller, S., Janke, S., Honermeier, B., Yan, F. and Azizi, A. (2016) Antioxidant capacity variation in the oregano ( Origanum vulgare L.) collection of the German National Genebank. Ind. Crops Prod. 92, 19-25. https://doi.org/10.1016/j.indcrop.2016.07.038.

5. Baranauskaite, J., Kubiliene, A., Marksa, M., Petrikaite, V., Vitkevičius, K., Baranauskas, A. and Bernatoniene, J. (2017) The influence of different oregano species on the antioxidant activity determined using HPLC postcolumn DPPH method and anticancer activity of carvacrol and rosmarinic acid. Biomed Res. Int. 2017. https://doi.org/10.1155/2017/1681392.

6. Tsimogiannis, D., Stavrakaki, M. and Oreopoulou, V. (2006) Isolation and characterisation of antioxidant components from oregano (Origanum heracleoticum). Int. J. Food Sci. Technol. 41, 39-48. https://doi.org/10.1111/j.1365-2621.2006.01259.x.

7. Sarikurkcu, C., Zengin, G., Oskay, M., Uysal, S., Ceylan, R. and Aktumsek, A. (2015) Composition, antioxidant, antimicrobial and enzyme inhibition activities of two Origanum vulgare subspecies (subsp. vulgare and subsp. hirtum) essential oils. Ind. Crops Prod. 70, 178-184. https://doi.org/10.1016/j.indcrop.2015.03.030. 
8. Vásquez Carreño, D. R. (2012)El orégano de monte (Lippia origanoides) del Alto Patía: Efecto del método de obtención de sus extractos sobre la composición y la actividad antioxidante de los mismos. Universidad Nacional de Colombia - Sede Bogotá.

9. Xiong, W., Yan, L., Xu, H., Shu, J., Han, F., Yang, M., Ma, G. and Zhao, Z. (2017) Chemical composition and antioxidant activities of essential oils from different parts of the oregano. $J$. Zhejiang Univ. B 18, 79-84. https://doi.org/10.1631/jzus.b1600377.

10. Rodríguez Salinas, P. A. (2014)Evaluación estacional de la producción y calidad del aceite esencial en plantas de orégano (Poliomintha longiflora Gray) en dos sistemas de cultivo. Universidad Autónoma de Nuevo León.

11. Milos, M., Mastelic, J. and Jerkovic, I. (2000) Chemical composition and antioxidant effect of glycosidically bound volatile compounds from oregano (Origanum vulgare L. ssp. hirtum). Food Chem. 71, 79-83. https://doi.org/10.1016/S0308-8146(00)00144-8.

12. Al-Kalaldeh, J. Z., Abu-Dahab, R. and Afifi, F. U. (2010) Volatile oil composition and antiproliferative activity of Laurus nobilis, Origanum syriacum, Origanum vulgare, and Salvia triloba against human breast adenocarcinoma cells. Nutr. Res. 30, 271-278. https://doi.org/10.1016/j.nutres.2010.04.001.

13. Novak, J., Johnson, C. B., Mitteregger, U., Skoula, M. and Kazantzis, A. (2004) Seasonal, populational and ontogenic variation in the volatile oil content and composition of individuals of Origanum vulgare subsp. Hirtum, assessed by GC headspace analysis and by SPME sampling of individual oil glands. Phytochem. Anal. 15, 286-292. https://doi.org/10.1002/pca.780.

14. Babili, F. El, Bouajila, J., Souchard, J. P., Bertrand, C., Bellvert, F., Fouraste, I., Moulis, C. and Valentin, A. (2011) Oregano: Chemical analysis and evaluation of its antimalarial, antioxidant, and cytotoxic activities. J. Food Sci. 76, 512-518. https://doi.org/10.1111/j.17503841.2011.02109.x.

15. Leyva-López, N., Gutiérrez-Grijalva, E. P., Vazquez-Olivo, G. and Heredia, J. B. (2017) Essential oils of oregano: Biological activity beyond their antimicrobial properties. Molecules 22. https://doi.org/10.3390/molecules22060989.

16. Si, W., Gong, J., Tsao, R., Zhou, T., Yu, H., Poppe, C., Johnson, R. and Du, Z. (2006) Antimicrobial activity of essential oils and structurally related synthetic food additives towards selected pathogenic and beneficial gut bacteria. J. Appl. Microbiol. 100, 296-305. https://doi.org/10.1111/j.1365-2672.2005.02789.x.

17. Taghvaei, M. and Jafari, S. M. (2015) Application and stability of natural antioxidants in 
edible oils in order to substitute synthetic additives. J. Food Sci. Technol. 52, 1272-1282. https://doi.org/10.1007/s13197-013-1080-1.

18. Kintzios, S. E. (2012) Oregano. In Handbook of Herbs and Spices: Second Edition Vol. Vol. 2 (Edited by Peter, K. V.), pp. 417-436. Woodhead Publishing, Cambridge. https://doi.org/10.1533/9780857095688.417.

19. Turek, C. and Stintzing, F. C. (2013) Stability of Essential Oils: A Review. 12, 40-53. https://doi.org/10.1111/1541-4337.12006.

20. Sköld, M., Börje, A., Harambasic, E. and Karlberg, A.-T. (2004) Contact Allergens Formed on Air Exposure of Linalool. Identification and Quantification of Primary and Secondary Oxidation Products and the Effect on Skin Sensitization. Chem. Res. Toxicol. 17, 1697-1705.

21. Hagvall, L., Carina, B., Norrby, P.-O., Karlberg, A.-T. and Anna, B. (2011) Experimental and Theoretical Investigations of the Autoxidation of Geranial : A Dioxolane Hydroperoxide Identified as a Skin Sensitizer. Chem. Res. Toxicol. 24, 1507-1515.

22. Wilkinson, F., Helman, W. P. and Ross, A. B. (1995) Rate Constants for the Decay and Reactions of the Lowest Electronically Excited Singlet State of Mol,ecular Oxygen in Solution. An Expanded and Revised CompUation. J. Phys. Chem. Ref. Data 24, 663-677.

23. Cerpa Chávez, M. G. (2007)Hidrodestilacion de aceites esenciales. Universidad de Valladolid.

24. Escalada, J. P., Pajares, A., Gianotti, J., Massad, W. A., Bertolotti, S., Amat-Guerri, F. and García, N. A. (2006) Dye-sensitized photodegradation of the fungicide carbendazim and related benzimidazoles. Chemosphere 65, 237-244. https://doi.org/10.1016/j.chemosphere.2006.02.057.

25. Silva, E., Herrera, L., Edwards, A. M., De La Fuente, J. and Lissi, E. (2005) Enhancement of riboflavin mediated photooxidation of glucose-6-phosphate-dehydrogenase by urocanic acid. Photochem. Photobiol. 81, 206-211. https://doi.org/10.1562/2004-07-14-RA-233.1.

26. Silva, E., Edwards, A. M. and Pacheco, D. (1999) Visible light-induced photooxidation of glucose sensitized by riboflavin. J. Nutr. Biochem. 10, 181-185. https://doi.org/10.1016/S09552863(98)00093-X.

27. Criado, S. and García, N. A. (2004) Vitamin B2- sensitized photooxidation of the ophthalmic drugs Timolol and Pindolol: kinetics and mechanism. Redox Rep. 9, 291-297. https://doi.org/10.1179/135100004225006047.

28. Neumann, M. and Garcia, N. A. (1992) Kinetics and Mechanism of the Light-Induced Deterioration of Lemon Oil. J. Agric. Food Chem. 40, 957-960. https://doi.org/10.1021/jf00018a008. 
29. Scully, F. E. and Hoigne, J. (1987) Rate constants for reactions of singlet oxygen with phenols and other compounds in water. Chemosphere 16, 681-694.

30. Massad, W. A., Bertolotti, S. G., Romero, M. and García, N. A. (2005) A kinetic study on the inhibitory action of sympathomimetic drugs towards photogenerated oxygen active species. The case of phenylephrine. J. Photochem. Photobiol. B 80, 130-138. https://doi.org/10.1016/j.jphotobiol.2005.03.010.

31. Ferrari, G. V., Natera, J., Paulina Montaña, M., Muñoz, V., Gutiérrez, E. L., Massad, W., Miskoski, S. and García, N. A. (2015) Scavenging of photogenerated ROS by Oxicams. Possible biological and environmental implications. J. Photochem. Photobiol. B Biol. 153, 233-239. https://doi.org/10.1016/j.jphotobiol.2015.09.024.

32. Muñoz, V. A., Ferrari, G. V., Montaña, M. P., Miskoski, S. and García, N. A. (2016) Effect of $\mathrm{Cu} 2+$-complexation on the scavenging ability of chrysin towards photogenerated singlet molecular oxygen $(\mathrm{O} 2(1 \Delta \mathrm{g}))$. Possible biological implications. J. Photochem. Photobiol. B Biol. 162, 597603. https://doi.org/10.1016/j.jphotobiol.2016.07.027.

33. Purpora, R., Massad, W., Ferrari, G., Reynoso, E., Criado, S., Miskoski, S., Pajares, A. and García, N. a (2013) The NSAIDs indomethacin and diflunisal as scavengers of photogenerated reactive oxygen species. Photochem. Photobiol. 89, 1463-70. https://doi.org/10.1111/php.12114.

34. Haggi, E., Blasich, N., Gutiérrez, L., Vázquez, G., Criado, S., Miskoski, S., Ferrari, G., Paulina Montaña, M. and García, N. a (2012) On the generation and quenching of reactiveoxygen-species by aqueous vitamin B2 and serotonin under visible-light irradiation. J. Photochem. Photobiol. B. 113, 22-8. https://doi.org/10.1016/j.jphotobiol.2012.04.010.

35. González, M., Tereschuk, M. L., Criado, S., Reynoso, E., Challier, C., Agüero, M. B., Luna, L., Ferrrari, G., Montaña, M. P. and García, N. A. (2015) The activity of propolis in the scavenging of vitamin B2-photogenerated ROS. Redox Rep. 20, 246-253. https://doi.org/10.1179/1351000215Y.0000000033.

36. Zang, L. Y. and Misra, H. P. (1992) Superoxide radical production during the autoxidation of 1-methyl-4- phenyl-2,3-dihydropyridinium perchlorate. J. Biol. Chem. 267, 17547-17552.

37. Baxter, R. M. and Carey, J. H. (1983) Evidence for photochemical generation of superoxide ion in humic waters. Nature 306, 575-576. https://doi.org/10.1038/306575a0.

38. Afanas'ev, I. B. (1989) Superoxide ion: Chemistry and biological implications, volume I. 1st ed. CRC Press, USA.

39. Cardoso, D. R., Olsen, K., Møller, J. K. S. and Skibsted, L. H. (2006) Phenol and terpene 
quenching of singlet- and triplet-excited states of riboflavin in relation to light-struck flavor formation in beer. J. Agric. Food Chem. 54, 5630-5636. https://doi.org/10.1021/jf060750d.

40. Criado, S., Bertolotti, S. G. and Garcfa, N. A. (1996) Kinetic aspects of the rose bengalsensitized photo-oxygenation of tryptophan alkyl esters. Ground state and photopromoted dyetryptophan derivative interactions. J. Photochem. Photobiol. , B Biol. 34, 79-86.

\section{TABLES}

Table 1. CR and TM content of OEO extracted from flower and leaf of oregano plants in different locations around the world.

\begin{tabular}{llccc}
\hline Location & Species & CR & TM & Ref \\
\hline Greece & Origanum heracleoticum & 42.53 & 1.24 & $(6)$ \\
Turkey & Origanum vulgare subsp. vulgare & 16.11 & 58.31 & $(7)$ \\
& Origanum vulgare subsp. hirtum & 0.33 & $(\mathrm{a})$ & \\
\multirow{2}{*}{ Colombia } & Lippia origanoides & 1.10 & 60.80 & $(8)$ \\
China & Origanum vulgare L. & 30.73 & 18.81 & $(9)$ \\
Jordan & Origanum syriacum & 41.10 & 0.43 & $(12)$ \\
\hline & a linalool was identified as a major component while & TM was not detected
\end{tabular}

Table 2. Identification of OEO components by GC: retention times (RT) and classification as major or minor component.

\begin{tabular}{ccc}
\hline Component & RT (min) & Classification \\
\hline o-cymene & 9.30 & Minor component \\
Trans-Sabinene Hydrate & 12.21 & Minor component \\
4-Terpineol & 15.70 & Minor component \\
$\alpha$-Terpineol & 16.11 & Minor component \\
\hline
\end{tabular}

This article is protected by copyright. All rights reserved 
Thymol

Carvacrol
$20.68-20.79$

21.06
First major component

Second major component

Table 3. Rate constants for the overall and reactive quenching of $\mathrm{O}_{2}\left({ }^{1} \Delta_{\mathrm{g}}\right)\left(k_{\mathrm{t}}\right.$ and $\left.k_{\mathrm{r}}\right), k_{\mathrm{r}} / k_{\mathrm{t}}$ ratio, rate constant for the quenching of singlet excited state of $\operatorname{Rf}\left({ }^{1} k_{\mathrm{q}}\right)$, rate constant for the quenching of triplet excited state of $\mathrm{Rf}\left({ }^{3} k_{\mathrm{q}}\right)$ in 60:40 $\mathrm{MeOH}: \mathrm{H}_{2} \mathrm{O}$ solvent, quantification of CR and TM in the OEO (\% w/v) and molar absorption coefficients of TM and CR

\begin{tabular}{|c|c|c|c|c|c|c|c|}
\hline System & $\begin{array}{c}{ }^{1} k_{\mathrm{q}} \times 10^{-10} \\
\mathbf{M}^{-1} \mathbf{s}^{-1}\end{array}$ & $\begin{array}{c}{ }^{3} k_{\mathrm{q}} \times 10^{-9} \\
\mathbf{M}^{-1} \mathbf{s}^{-1}\end{array}$ & $\begin{array}{l}k_{\mathrm{t}} \times 10^{-6} \\
M^{-1} \mathrm{~s}^{-1}\end{array}$ & $\begin{array}{c}k_{\mathrm{r}} \times 10^{-6} \\
M^{-1} \mathbf{s}^{-1}\end{array}$ & $\boldsymbol{k}_{\mathrm{r}} / \boldsymbol{k}_{\mathrm{t}}$ & $\% \mathrm{w} / \mathrm{v}$ & $\begin{array}{c}\varepsilon_{274 \mathrm{~nm}} \\
\mathbf{M}^{-1} \mathbf{c m}^{-1}\end{array}$ \\
\hline TM & 0.57 & 1.50 & 5.6 & 1.7 & 0.3 & 47.5 & 2160.5 \\
\hline $\mathrm{CR}$ & 0.48 & 2.23 & 4.7 & 1.1 & 0.2 & 7.1 & 2220.7 \\
\hline OEO & 1.74 & 1.45 & 4.6 & 2.4 & 0.5 & - & - \\
\hline
\end{tabular}

\section{FIGURE CAPTIONS}

Figure 1. Structures of carvacrol (CR) and thymol (TM).

Figure 2. Chromatogram of Origanum Vulgare essential oil.

Figure 3. Absorption spectra of A) TM; B) CR; C) OEO and D) Rf in 60:40 MeOH: $\mathrm{H}_{2} \mathrm{O}$ solvent.

Figure 4. Spectral evolution of $\mathrm{OEO}\left(\mathrm{TM}_{\mathrm{OEO}}=0.2 \mathrm{mM}\right)+\mathrm{Rf}(0.05 \mathrm{mM})$ vs. Rf $(0.05 \mathrm{mM})$ irradiated using $400 \mathrm{~nm}$ cut-off filter and $\mathrm{MeOH}: \mathrm{H}_{2} \mathrm{O}$ 60:40 v/v as solvent. Inset: Spectral evolution of $\mathrm{Rf}(0.05 \mathrm{mM})$ irradiated using $400 \mathrm{~nm}$ cut-off filter and $\mathrm{MeOH}: \mathrm{H}_{2} \mathrm{O} 60: 40 \mathrm{v} / \mathrm{v}$ as solvent. 
Figure 5. Left: Profiles of oxygen uptake vs. irradiation time of the mixtures: a) $\mathrm{Rf}+\mathrm{TM}+\mathrm{NaN}_{3}$; b) $\mathrm{Rf}+\mathrm{TM}+\mathrm{CAT}$; c) $\mathrm{Rf}+\mathrm{TM}$; d) $\mathrm{Rf}+\mathrm{TM}+\mathrm{SOD}$. Right: Profiles of oxygen uptake vs. irradiation time of the mixtures: a) $\mathrm{Rf}+\mathrm{CR}+\mathrm{NaN}_{3}$; b) $\mathrm{Rf}+\mathrm{CR}$; c) $\mathrm{Rf}+\mathrm{CR}+\mathrm{SOD}$; d) $\mathrm{Rf}+\mathrm{CR}+\mathrm{CAT}$. [Rf] $=0.04$ $\mathrm{mM} ;[\mathrm{TM}]=[\mathrm{CR}]=0.2 \mathrm{mM} ;\left[\mathrm{NaN}_{3}\right]=5 \mathrm{mM} ;[\mathrm{SOD}]=[\mathrm{CAT}]=1 \mu \mathrm{g} / \mathrm{mL}$. Solvent: $60: 40 \mathrm{MeOH}: \mathrm{H}_{2} \mathrm{O}$. $\lambda_{\text {irr }}>400 \mathrm{~nm}$.

Figure 6. Left: Oxygen consumption profiles vs irradiation time of the mixtures: a) $\mathrm{Rf}+\mathrm{OEO}+\mathrm{NaN}_{3}$; b) $\mathrm{Rf}+\mathrm{OEO} ;$ c) $\mathrm{Rf}+\mathrm{OEO}+\mathrm{CAT} ;$ d) $\mathrm{Rf}+\mathrm{OEO}+\mathrm{SOD} . \quad[\mathrm{Rf}]=0.04 \quad \mathrm{mM}$; $[\mathrm{OEO}]=\mathrm{TM}_{\mathrm{OEO}}=0.2 \mathrm{mM} ;\left[\mathrm{NaN}_{3}\right]=5 \mathrm{mM} ;[\mathrm{SOD}]=[\mathrm{CAT}]=1 \mu \mathrm{g} / \mathrm{mL}$. Solvent: 60:40 MeOH:H $\mathrm{H}_{2} \mathrm{O}$. $\lambda_{\text {irr }}>400 \mathrm{~nm}$. Right: Oxygen consumption profiles vs irradiation time of the mixtures: a) $\mathrm{Rf}+\mathrm{TM}+\mathrm{CR}+\mathrm{NaN}_{3}$; b) $\mathrm{Rf}+\mathrm{TM}+\mathrm{CR}+\mathrm{CAT}$; c) $\mathrm{Rf}+\mathrm{TM}+\mathrm{CR}$; d) $\mathrm{Rf}+\mathrm{TM}+\mathrm{CR}+\mathrm{SOD}$. [Rf]=0.04 mM; $[\mathrm{TM}]=0.2 \mathrm{mM} ; \quad[\mathrm{CR}]=0.03 \mathrm{mM} ; \quad\left[\mathrm{NaN}_{3}\right]=5 \mathrm{mM} ; \quad[\mathrm{SOD}]=[\mathrm{CAT}]=1 \mu \mathrm{g} / \mathrm{mL}$. Solvent: $60: 40$ $\mathrm{MeOH}: \mathrm{H}_{2} \mathrm{O} . \lambda_{\mathrm{irr}}>400 \mathrm{~nm}$.

Figure 7. Left: Stern-Volmer plots for the deactivation rate of ${ }^{3} \mathrm{Rf}^{*},{ }^{3} k_{\mathrm{q}}$, by A) CR; B) OEO and C) TM. . Right: Fluorescence spectra of Rf quenching by OEO Inset:Stern-Volmer plots for the determination ${ }^{1} k_{\mathrm{q}}$ by $\left.\mathbf{A}\right) \mathrm{CR}$; B) OEO and C) TM.

Figure 8. Stern - Volmer plots for the determination of the rate constant of total deactivation of $\mathrm{O}_{2}\left({ }^{1} \Delta_{\mathrm{g}}\right)$ photogenerated from RB by A) TM, B) OEO and C) CR. Inset: Oxygen consumption profiles vs irradiation time of the mixtures: A) RB + CR; B) RB+TM; C) RB+OEO; D) RB+FFA. $[\mathrm{Rf}]=0.04 \mathrm{mM} ;[\mathrm{OEO}]=\mathrm{TMOEO}=[\mathrm{CR}]=[\mathrm{TM}]=[\mathrm{FFA}]=0.2 \mathrm{mM}$. Solvent: $60: 40 \mathrm{MeOH}: \mathrm{H}_{2} \mathrm{O} . \lambda \operatorname{irr}>$ $400 \mathrm{~nm}$ cut off filter.

Figure 9. Rate of oxygen uptake (ROU) of: a) $\mathrm{Rf}+\mathrm{Trp}$; b) $\mathrm{Rf}+\mathrm{OEO}$; c) $\mathrm{Rf}+\mathrm{Trp}+\mathrm{OEO}$. [Rf]=0.04 $\mathrm{mM} ;[\mathrm{OEO}]=\mathrm{TM}_{\mathrm{OEO}}=[\mathrm{CR}]=[\mathrm{TM}]=[\mathrm{FFA}]=0.2 \mathrm{mM}$. Solvent: $60: 40 \mathrm{MeOH}: \mathrm{H}_{2} \mathrm{O}$. $\lambda$ irr $>400 \mathrm{~nm}$ cut off filter. 
<smiles>Cc1ccc(C(C)C)cc1O</smiles>

Carvacrol<smiles>Cc1ccc(C(C)C)c(O)c1</smiles>

Thymol

Figure 1. 


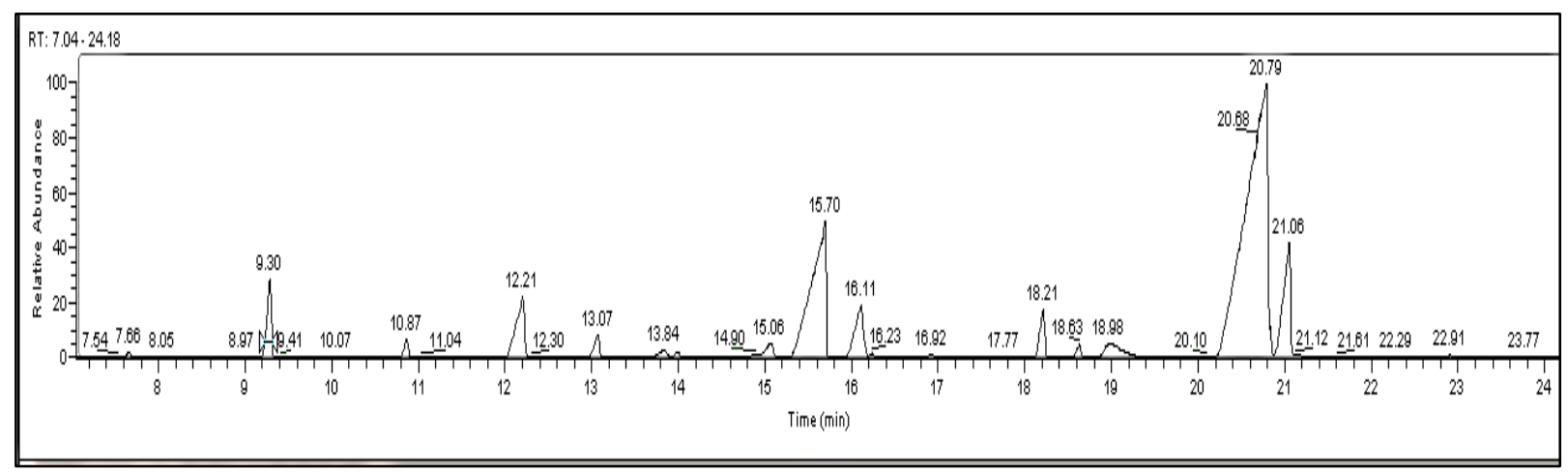

Figure 2 


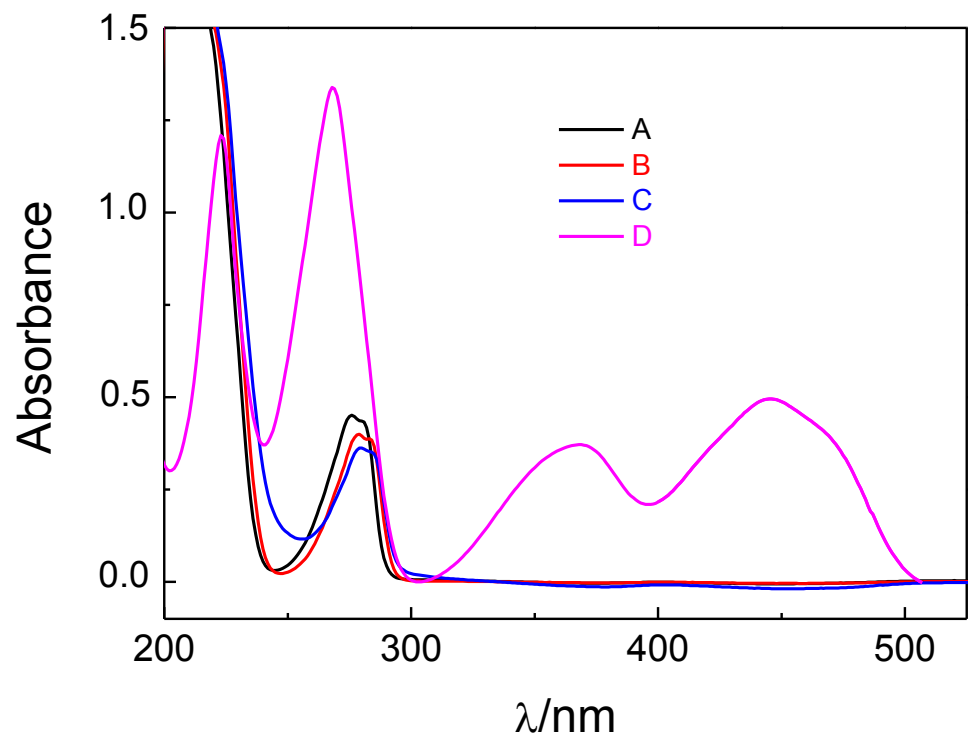

Figure 3 


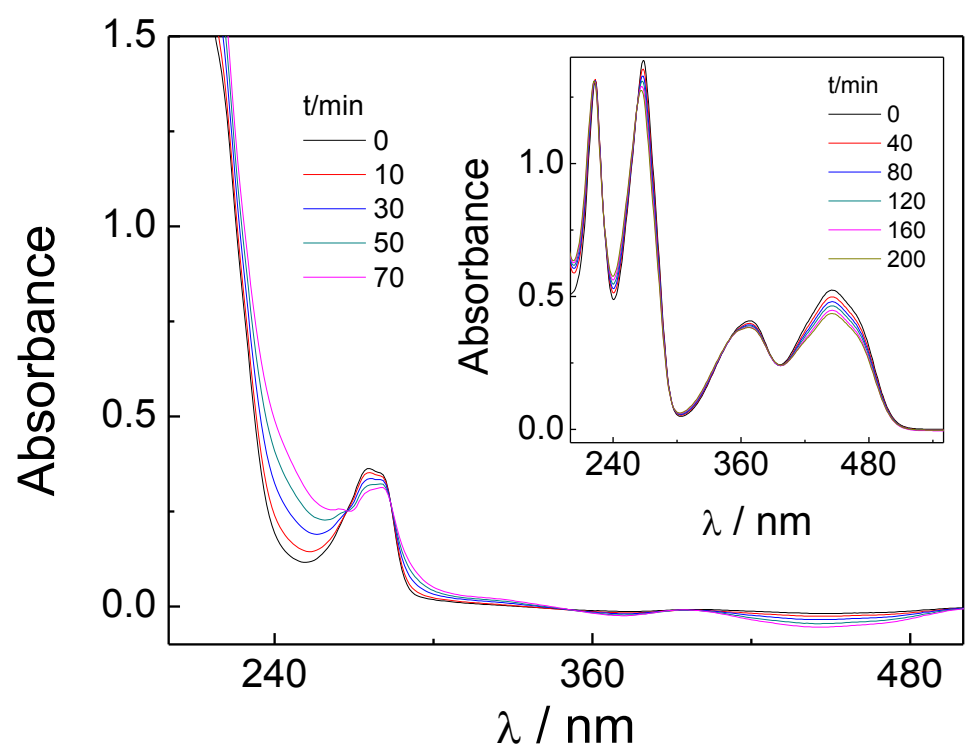

Figure 4 

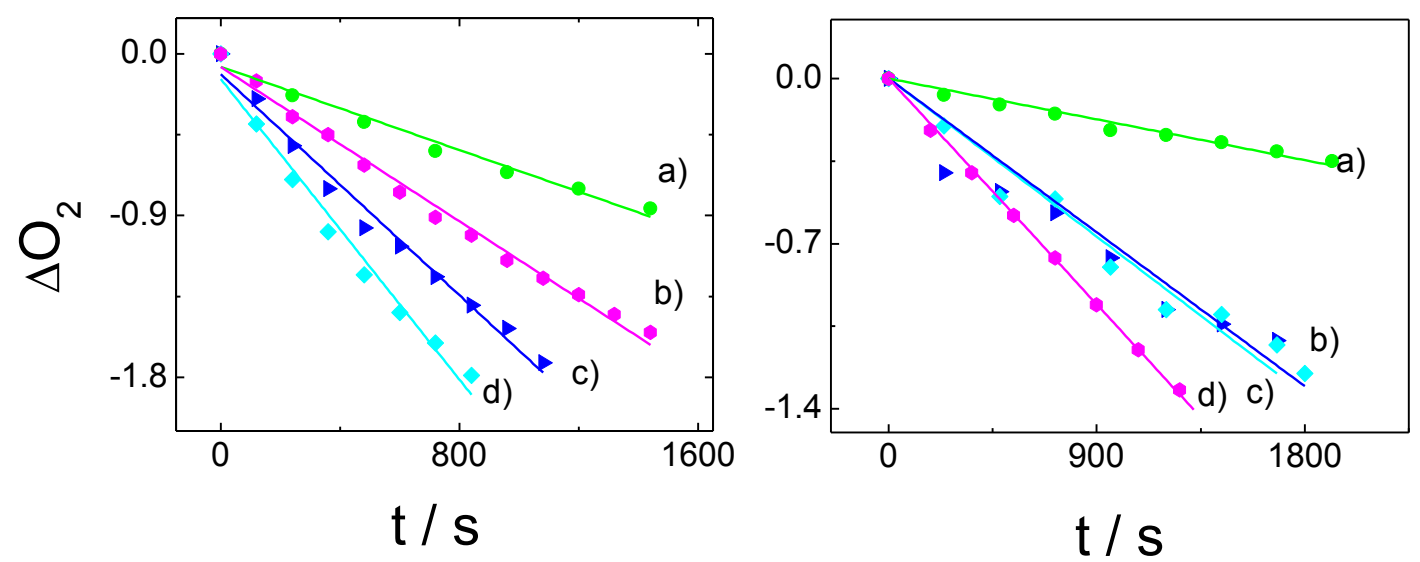

Figure 5

This article is protected by copyright. All rights reserved 

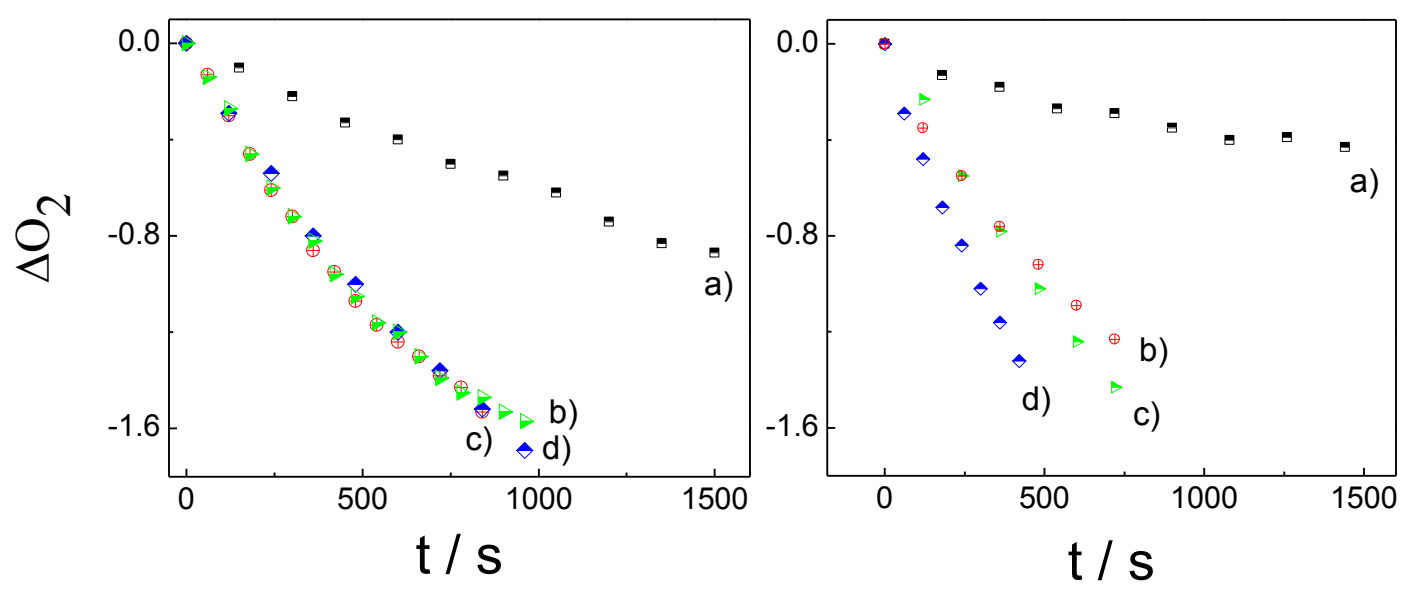

Figure 6

This article is protected by copyright. All rights reserved 

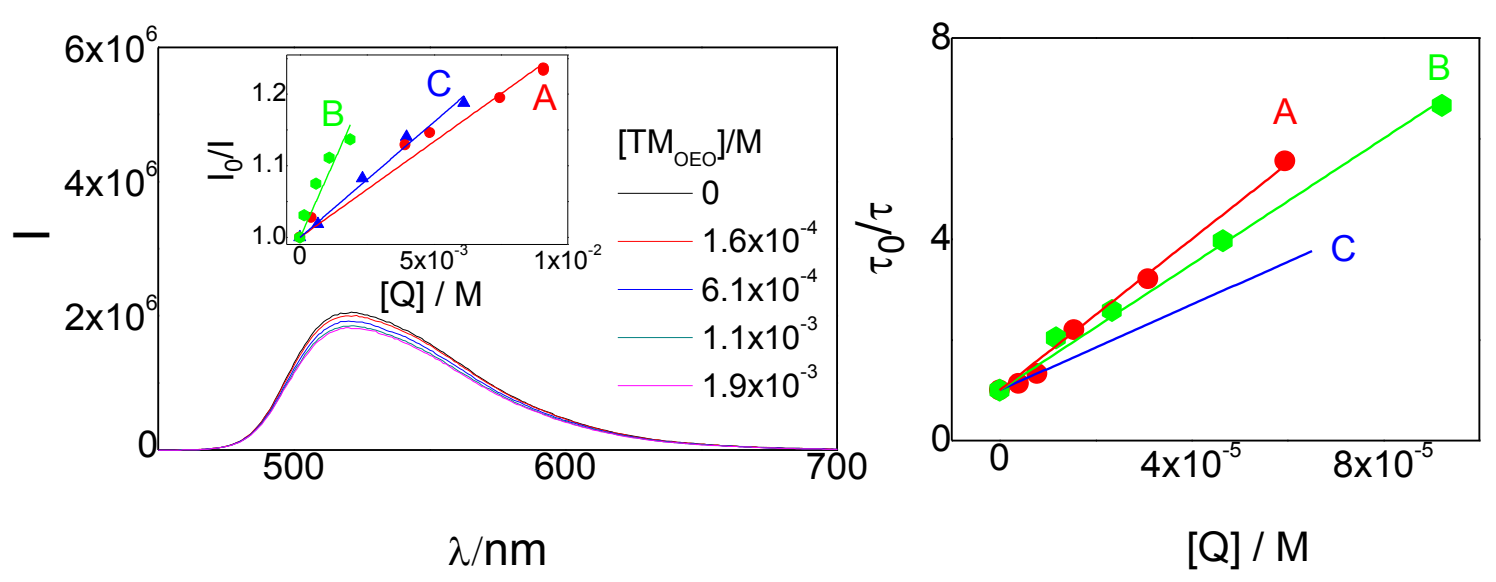

Figure 7

This article is protected by copyright. All rights reserved 


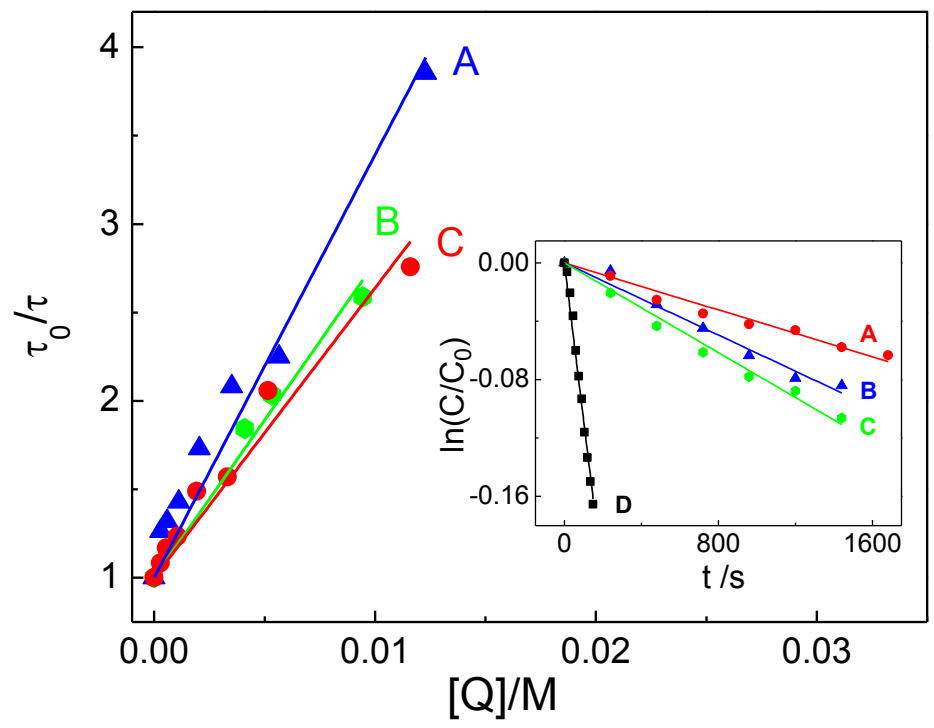

Figure 8

This article is protected by copyright. All rights reserved 


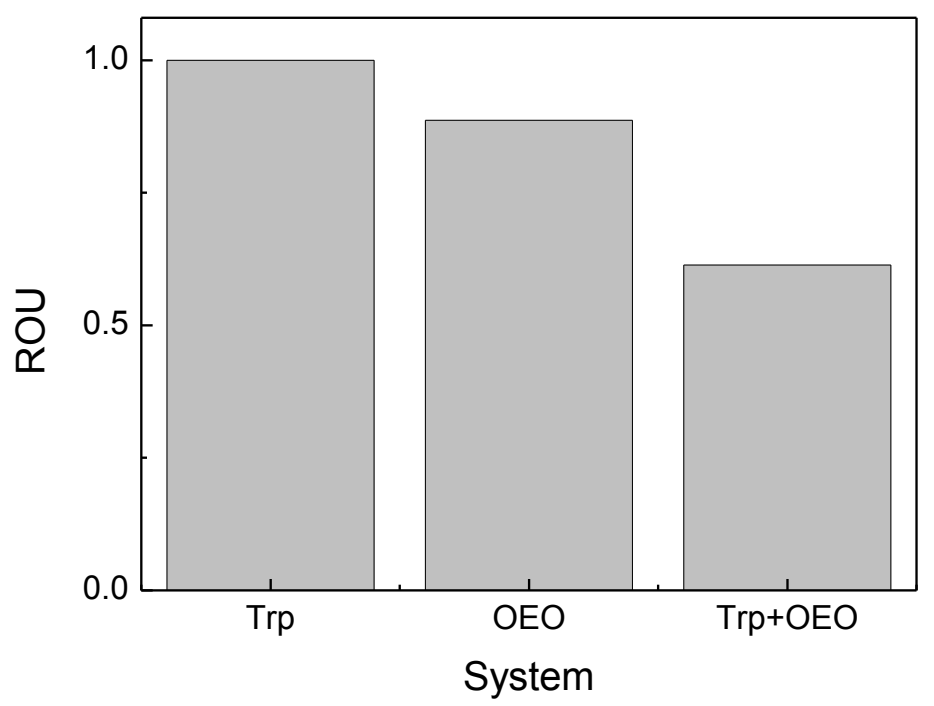

Figure 9

This article is protected by copyright. All rights reserved 